\title{
ANALISIS TINGKAT KESEHATAN BANK PADA PT. BANK PERKREDITAN RAKYAT (BPR) JORONG KAMPUANG TANGAH PARIAMAN CABANG PADANG
}

\author{
Yora Aprilia Putri, Doni Marlius \\ Akademi Keuangan Dan Perbankan Padang \\ donimarlius@akbpstie.ac.id
}

\begin{abstract}
The purpose of this study is to determine the level of bank health at PT. Bank Perkreditan Rakyat (BPR) Jorong Kampuang Tangah Pariaman Cabang Padang that should be done by the bank in minimizing problems that occur. This research focused on: Analysis of Bank Health Level At PT. Bank Perkreditan Rakyat (BPR) Jorong Kampuang Tangah Pariaman Cabang Padang. The result of this research is Bank Health Level Analysis of PT. BPR-JKT Pariaman Cabang Padang which can be seen in several process stages from the level of health, data or file validity assessment, CAMEL analysis that is, analysis of Capital Adequacy Ratio (CAR) which decreased by 2015 by $15 \%$ and decrease in 2016 by $11 \%$ due to no decrease or increase in capital, while the CAR of 2015-2016 is above the BI standard of 8\% which means healthy. Ratio of BPRJKT Cabang Pariaman Padang is under $10.35 \%$ in healthy category, as well as ROA owned in healthy condition while Ratio LDR PT. BPR-JKT Pariaman Cabang Padang is not in the healthy category by 2015-2016 the bank can not keep LDR below $94.75 \%$.
\end{abstract}

Keywords: Bank soundness

\section{PENDAHULUAN}

Dunia perbankan merupakan salah satu institusi yang sangat berperan penting dalam bidang perekonomian suatu Negara (khususnya dibidang pembiayaan, perekonomian dan pembangunan). Perbankan adalah segala sesuatu yang menyangkut tentang bank, kelembagaan, kegiatan usaha, serta cara dan proses dalam melaksanakan kegiatan usahanya. (Imamah, 2012) Bank adalah suatu badan usaha yang berfungsi menghimpun dana dari masyarakat dalam bentuk simpanan dan menyalurkannya kepada masyarakat dalam bentuk kredit dan atau bentuk-bentuk lainnya dalam rangka meningkatkan taraf hidup rakyat banyak.

Dilihat dari segi fungsinya, bank dibagi menjadi dua yaitu Bank Umum dan Bank perkreditan Rakyat (BPR). Pada zaman sekarang ini Bank Perkreditan Rakyat (BPR) memiliki pasar tersendiri di masyarakat. Menurut (Imamah, 2012) Pada umumnya masyarakat yang mempunyai usaha kecil menengah cenderung memilih Bank Perkreditan Rakyat (BPR) sebagai tempat untuk mengembangkan usahanya dengan meminjam uang dengan bunga kredit kecil dan prosedur peminjamannya mudah dengan didukung oleh manajemen

Dalam API disebutkan bahwa daya saing BPR diperkuat melalui kegiatan meningkatkan linkage program antar bank umun dengan BPR, mempermudah pembukaan kantor cabang BPR, dan memfasilitasi pembentukan fasilitas jasa bersama untuk BPR. Dengan demikian, Bank Perkreditan Rakyat (BPR) yang merupakan bagian dari sistem Perbankan yang harus sehat dan dapat di percaya oleh masyarakat agar bisa 
berkontribusi maksimal dalam menggerakkan dan membangun perekonomian daerah secara sehat dan menyeluruh.

Berdasarkan Surat Edaran Bank Indonesia No.6/23/DPNP tanggal 31 Mei 2004, penilaian tingkat kesehatan bank merupakan penilaian kualitatif atas berbagai aspek yang berpengaruh terhadap kondisi atau kinerja suatu bank melalui penilaian aspek permodalan, kualitas asset, manajemen, rentabilitas, likuiditas dan sensitivitas terhadap resiko pasar. Penggolongan tingkat kesehatan bank dibagi dalam empat kagetori yaitu : sehat, cukup sehat, kurang sehat, dan tidak sehat.

Kesehatan BPR adalah suatu bentuk penilaian konsumen atau masyarakat terhadap tingkat perkembangan suatu bank yang mana nantinya menjadi pengaruh besar bagi masyarakat untuk bergabung pada bank tersebut. Bank yang sehat dijadikan sebagai patokan oleh masyarakat bahwa bank tersebut mampu berkembang dan dapat bersaing, serta mampu bertahan pada masanya.

PT. Bank Perkreditan Rakyat Jorong Kampuang Tangah Pariaman Cabang Padang atau biasa disingkat dengan PT. BPR-JKT Pariaman Cabang Padang merupakan salah satu cabang dari PT. BPR-JKT Pariaman yang berpusat di Pariaman. PT. BPRJKT Pariaman Cabang Padang ini terletak di Jl. Adinegoro, Lubuak Buaya, kota Padang. BPR ini berperan memberikan kontribusi aktif bagi keberhasilan pelaksanaan pembangunan khususnya di bidang penyediaan modal bagi masyarakat. Salah satu indikator yang di gunakan untuk menilai keberhasilan atau kegagalan BPR dalam mencapai tujuan tersebut adalah laporan kinerja keuangan perusahaan yang telah dicapai. Penilaian atau analisa kinerja keuangan suatu BPR sangat penting begitu juga bagi semua jenis usaha yang bertujuan untuk mencapai laba, serta untuk peningkatan dan perkembangan PT. BPR-JKT Pariaman untuk masa yang akan datang.

Laporan mengenai data keuangan PT. BPR-JKT Pariaman dalam kurun waktu 2015 dan 2016, dapat dilihat pada tabel berikut ini :

Tabel 1

Data Keuangan PT. BPR-JKT Pariaman Cabang Padang Tahun 2015 dan 2016 (Ribuan Rp.)

\begin{tabular}{|c|c|c|}
\hline Indikator & $\mathbf{2 0 1 5}$ & $\mathbf{2 0 1 6}$ \\
\hline Modal & 3.122 .850 & 3.122 .850 \\
\hline ATMR & $20.566 .069,6$ & $27.395 .147,8$ \\
\hline Laba sebelum pajak & 1.097 .646 & 830.432 \\
\hline Total asset & 25.707 .588 & 30.512 .806 \\
\hline Kredit yang diberikan & 18.828 .879 & 25.878 .644 \\
\hline Dana pihak ketiga & 15.084 .125 & 18.563 .328 \\
\hline APYD & 473.706 & $520.659,5$ \\
\hline Jumlah asset produktif & 18.595 .114 & 25.583 .680 \\
\hline
\end{tabular}

Sumber: Laporan Keuangan PT. BPR-JKT Pariaman Cabang Padang

Tabel 1 Mengidentifikasi bahwa terdapat fluktuasi atau ketidak tepatan rasio, karna adanya peningkatan dan penurunan nilai keuangan, seperti modal (CAR), ATMR, 
laba sebelum pajak, total asset, kredit yang diberikan, dana pihak ketiga, APYD, dan jumlah asset produktif dari PT. BPR-JKT Pariaman Cabang Padang.

CAR berdasarkan standar Bank Indonesia minimal 8\% tergolong sehat pada tahun 2015 CAR BPR-JKT Pariaman Cabang Padang pada modal 2015 adalah 3.122.850 dan tahun 2016 dengan nilai 3.122.850 artinya modal BPR-JKT Pariaman Cabang Padang berada pada posisi yang sama, tidak ada peningkatan ataupun penurunan. Untuk ATMR pada tahun 2015 sebesar 20.566.069,6 dan ditahun 2016 sebesar 27.395.147,8, berarti ATMR dari tahun 2015 ke tahun 2016 mengalami peningkatan sebesar 6.829.078,2 . Untuk laba sebelum pajak dari tahun 2015 ke tahun 2016 mengalami penurunan sebesar 267.214. Untuk total aktiva dari tahun 2015 ke tahun 2016 mengalami peningkatan sebanyak 4.805.218. Untuk kredit yang diberikan dari tahun 2015 ke tahun 2016 mengalami peningkatan sebanyak 7.049.765. Untuk dana pihak ketiga dari tahun 2015 ke tahun 2016 mengalami peningkatan sebanyak 3.479.203. Sedangkan untuk APYD dari tahun 2015 ke tahun 2016 mengalami peningkatan sebesar 46.953,5, dan pada jumlah asset produktif dari tahun 2015 ke tahun 2016 juga mengalami peningkatan sebesar 6.988.566.

Secara keseluruhan data keuangan PT. BPR BPR-JKT Pariaman Cabang Padang 2015-2016 mengalami peningkatan, namun laba sebelum pajak dari tahun 2015 ke tahun 2016 mengalami penurunan. Melihat kenyataan diatas, maka sangat penting bagi bank untuk menganalisis tingkat kesehatan bank untuk mempertahankan kelangsungan operasional bank dalam menghadapi persaingan. Oleh karena itu diperlukan metode CAMEL yaitu Capital (Permodalan), Asset quality (kualitas asset), Management (manajemen), Earning (rentabilitas), dan Liquidity (likuiditas).

Berdasarkan uaraian tersebut maka penulis tertarik untuk menganalisis dan menuangkan dalam bentuk tugas akhir yang berjudul "Analisis Tingkat Kesehatan Bank Pada PT. Bank Perkreditan Rakyat Jorong Kampuang Tangah Pariaman Cabang Padang".

Berdasarkan uraian latar belakang diatas, maka rumusan masalah dalam penelitian ini adalah "Bagaimana tingkat kesehatan bank pada PT. Bank Perkreditan Rakyat Jorong Kampuang Tangah Pariaman Cabang Padang dengan menggunakan metode CAMEL selama periode tahun 2015 dan 2016 berada dalam kondisi sehat?"

Penelitian ini bertujuan untuk mengetahui bagaimana tingkat kesehatan bank pada PT. Bank Perkreditan Rakyat Jorong Kampuang Tangah Pariaman Cabang Padang dengan menggunakan metode CAMEL selama periode tahun 2015 dan 2016 berada dalam kondisi sehat.

Adapun manfaat penelitian ini, penulis berharap dapat bermanfaat antara lain: a. Bagi perusahaan sebagai tolok ukur bagi manajemen PT. Bank Perkreditan Rakyat Jorong Kampuang Tangah Pariaman Cabang Padang untuk menilai apakah pengelolaan bank sudah dilaksanakan dengan baik sesuai dengan peraturan yang telah ditetapkan dan sebagai acuan untuk menentukan strategi usaha dan kebijakan dimasa akan datang. b. Bagi penulis untuk memenuhi salah satu syarat untuk mencapai gelar Diploma III Keuangan dan Perbankan di AKBP Padang. c. Sebagai referensi bagi penelitian sejenis.

\section{METODE PENELITIAN}

Dalam pengumpulan data dan bahan untuk melakukan penelitian ini, penulis menggunakan metode dengan dua cara sebagai berikut : a. Peninjauan Langsung Ke Objek yaitu Peninjauan langsung ke objek penelitian dipilih untuk meneliti hasil data primer. Penelitian langsung ke lapangan ini akan dapat membantu penulis untuk 
melengkapi data yang diperlukan. Adapun cara riset lapangan ini adalah dengan mewawancarai pihak-pihak yang berkepentingan dalam hal ini adalah perusahaan atau instansi yang terkait. b. Studi Kepustakaan (Library Research) yaitu Penelitian ini dilakukan dengan cara mempelajari buku-buku, makalah-makalah, artikel-artikel, bacaan laporan-laporan dan publikasi yang berhubungan dengan objek penelitian.

\section{HASIL DAN PEMBAHASAN}

1. Permodalan ( Capital)

Menurut (Jacob, 2013) Keberhasilan suatu bank bukan hanya terletak pada jumlah modal yang dimilikinya melainkan di dasarkan kepada bagaimana bank tersebut mempergunakan modalnya untuk menarik sebanyak mungkin dana / simpanan masyarakat yang kemudian nantinya akan di salurkan kembali kepada masyarakat yang membutuhkannya sehingga memberntuk pendapatan bagi bank tersebut

Rasio ini digunakan untuk mengukur sejauh mana penurunan yang terjadi dalam total aktiva yang bisa ditutupi oleh modal yang tersedia. Penilaian terhadap pemodalan PT. BPR-JKT Pariaman Cabang Padang menggunakan rasio CAR yang merupakan perbandingan antara modal dengan aktiva tertimbang menurut resiko. Dapat diketahui pada tabel dibawah ini:

Tabel 2

CAR PT. BPR-JKT Pariaman Cabang Padang tahun 2015-2016

\begin{tabular}{|c|r|r|r|r|}
\hline \multirow{2}{*}{ Keterangan } & \multicolumn{2}{|c|}{2015} & \multicolumn{2}{c|}{$\mathbf{2 0 1 6}$} \\
\cline { 2 - 5 } & $\begin{array}{c}\text { Jumlah } \\
\text { (Ribuan Rp.) }\end{array}$ & $\begin{array}{c}\text { Peningkatan } \\
\text { (\%) }\end{array}$ & $\begin{array}{c}\text { Jumlah } \\
\text { (Ribuan Rp.) }\end{array}$ & $\begin{array}{c}\text { Peningkatan } \\
\text { (\%) }\end{array}$ \\
\hline a. Jumlahmodal & 3.122 .850 & - & 3.122 .850 & 0 \\
\hline b. Jumlah ATMR & $20.566 .069, \varnothing$ & - & $27.395 .147,8$ & $33,20 \%$ \\
\hline CAR= a/b×100\% & \multicolumn{2}{|c|}{$15 \%$} & $11 \%$ \\
\hline $\begin{array}{c}\text { Sumber : Data Olahan } \\
\text { Perhitungan nilai kredit (NK) rasio CAR }\end{array}$
\end{tabular}

$$
\begin{gathered}
N K=\frac{\text { Rasio }}{0,1 \%}+1 \\
N K 2015=\frac{15 \%}{0,1 \%}+1=151 \% \\
N K 2016=\frac{11 \%}{0,1 \%}+1=111 \%
\end{gathered}
$$

Dari tabel 2 diatas dapat dilihat bahwa resiko kecukupan modal (CAR) mengalami penurunan, karena pada tahun 2015 sebesar $15 \%$. Yang mana peningkatan ATMR 33,20\% sedangkan untuk CAR tahun 2015-2016 lebih besar dari $8 \%$ berarti dikatakan SEHAT dalam menyediakan pemodalannya untuk menghadapi resiko-resiko yang mungkin timbul .

2. Kualitas Aktiva Produktif (Assets Quality)

Penilaian KAP yang dimiliki dapat diukur dengan 2 cara yaitu :

a. Rasio KAP/ APYD terhadap Aktiva Produktif

Raio KAP/ APYD terhadap Aktiva Produktif adalah penjumlahan aktiva produktif yang tergolong non lancar setelah dikalikan bobotnya. Rasio ini digunakan untuk mengukur tingkat kemungkinan diterimanya kembali dana yang ditanamkan. Semakin kecil rasio KAP, maka semakin besar tingkat kemungkinan 
diterimanya kembali dana yang ditanamkan. APYD menggambarkan Aktiva Produktif yang kurang lancar, diragukan atau macet.

Tabel 3

Laporan Kolektibilitas Aktiva Produktif

PT. BPR-JKT Pariaman Cabang Padang Tahun 2015

\begin{tabular}{|c|c|c|c|}
\hline Komponen & $\begin{array}{c}\text { Nominal } \\
\text { (Ribuan Rp.) }\end{array}$ & $\begin{array}{c}\text { Bobot } \\
(\%)\end{array}$ & $\begin{array}{c}\text { Aktiva yang } \\
\text { diklasifikasikan } \\
\text { ( Ribuan Rp.) }\end{array}$ \\
\hline $\begin{array}{l}\text { A. oAktiva Produktif yang Diklasifikasikan(APYD) } \\
\text { - Lancar } \\
\text { - Kurang Lancar } \\
\text {-Diragukan } \\
\text {-Macet } \\
\text { Jumlah APYD }\end{array}$ & $\begin{array}{r}24.409 .280 \\
112.215 \\
11.534 \\
408.948\end{array}$ & $\begin{array}{l}0 \% \\
50 \% \\
75 \% \\
100 \%\end{array}$ & $\begin{array}{r}0 \\
56.107,5 \\
8.650,5 \\
408.948 \\
\mathbf{4 7 3 . 7 0 6}\end{array}$ \\
\hline $\begin{array}{l}\text { B. Aktiva Produktif(AP) } \\
\text { · Kredit yang Diberikan } \\
\text { · Penempatan pada Bank Lain } \\
\text { Jumlah Aktiva Produktif }\end{array}$ & $\begin{array}{r}18.828 .879 \\
6.133 .098\end{array}$ & & 24.961 .977 \\
\hline
\end{tabular}

Sumber: Data Olahan

Tabel 4

Laporan Kolektibilitas Aktiva Produktif

PT. BPR-JKT Pariaman Cabang Padang Tahun 2016

\begin{tabular}{|c|c|c|c|}
\hline Komponen & $\begin{array}{c}\text { Nominal } \\
\text { (Ribuan Rp.) }\end{array}$ & $\begin{array}{c}\text { Bobot } \\
(\%)\end{array}$ & $\begin{array}{c}\text { Aktiva yang } \\
\text { diklasifikasikan } \\
\text { (Ribuan Rp.) }\end{array}$ \\
\hline $\begin{array}{l}\text { A. Aktiva Produktif yang Diklasifikasikan (APYD) } \\
\text { - Lancar } \\
\text { - Kurang Lancar } \\
\text { · Diragukan } \\
\text { - Macet } \\
\text { Jumlah APYD }\end{array}$ & $\begin{array}{r}28.765 .261 \\
0 \\
183.510 \\
383.027\end{array}$ & $\begin{array}{l}0 \% \\
50 \% \\
75 \% \\
100 \%\end{array}$ & $\begin{array}{r}0 \\
0 \\
137.632,5 \\
383.027 \\
\mathbf{5 2 0 . 6 5 9 , 5}\end{array}$ \\
\hline $\begin{array}{l}\text { B. Aktiva Produktif(AP) } \\
\text { Kredit yang Diberikan } \\
\text { Penempatan pada Bank Lain } \\
\text { Jumlah AP }\end{array}$ & $\begin{array}{r}25.878 .644 \\
3.453 .154\end{array}$ & & 29.331.798 \\
\hline
\end{tabular}

Sumber: Data Olahan

Perhitungan Rasio KAP PT. BPR-JKT Pariaman Cabang Padang adalah sebagai berikut:

$$
\begin{gathered}
K A P=\frac{\text { Jumlah Aktiva Produktif yan Diklasifikasikan }}{\text { Jumlah Aktiva Produktif }} \times 100 \% \\
K A P 2015=\frac{473.706}{24.961 .977} \times 100 \%=0,01 \% \\
K A P 2016=\frac{520.659,5}{29.331 .798} \times 100 \%=0,01 \%
\end{gathered}
$$

Perhitungan nilai kredit $(\mathrm{NK})$ rasio KAP :

$$
\begin{aligned}
& N K 2015=\frac{22,5 \%-0,01 \%}{0,15 \%}=149(\text { maksimum } 100) \\
& N K 2016=\frac{22,5 \%-0,01 \%}{0,15 \%}=149(\text { maksimum } 100)
\end{aligned}
$$

BPR-JKT Pariaman Cabang Padang selama periode 2015-2016 mampu menjaga rasio KAP dibawah 10,35\% sehingga berdasarkan kriteria penilaian rasio 
KAP BPR-JKT Pariaman Cabang Padang dapat dikategorikan dalam kelompok SEHAT.

b. Rasio PPAP

PPAP yaitu penyisihan penghapusan aktiva produktif yang dibentuk guna menutup risiko kemungkinan kerugian. Semakin besar PPAP maka modal bank akan semakin kecil karena besarnya PPAP ini dicadangkan dari modal. Berikut hasil perhitungan rasio PPAP pada BPR-JKT Pariaman Cabang Padang tahun 2015-2016:

Tabel 5

Laporan Kolektibilitas Aktiva Produktif

PT. BPR-JKT Pariaman Cabang Padang Tahun 2015

\begin{tabular}{|l|r|r|r|}
\hline \multicolumn{1}{|c|}{ Komponen } & \multicolumn{1}{|c|}{$\begin{array}{c}\text { Nominal } \\
\text { (Ribuan Rp.) }\end{array}$} & $\begin{array}{c}\text { Bobot } \\
(\mathbf{\%})\end{array}$ & $\begin{array}{c}\text { Aktiva yang diklasifikasikan } \\
\text { (Ribuan Rp.) }\end{array}$ \\
\hline PPAP & & & $\mathbf{3 4 . 4 2 4}$ \\
\hline PPAPWD & 24.409 .280 & $0,5 \%$ & $122.046,4$ \\
- Lancar & 112.215 & $10 \%$ & $11.221,5$ \\
-Kurang lancar & 11.534 & $50 \%$ & 5.767 \\
-Diragukan & 408.948 & $100 \%$ & 408.948 \\
-Macet & & & $\mathbf{5 4 7 . 9 8 2 , 9}$ \\
Jumlah PPAPWD & &
\end{tabular}

Sumber : Data Olahan

Tabel 6

Laporan Kolektibilitas Aktiva Produktif

PT. BPR-JKT Pariaman Cabang Padang Tahun 2016

\begin{tabular}{|l|r|r|r|}
\hline \multicolumn{1}{|c|}{ Komponen } & $\begin{array}{c}\text { Nominal } \\
\text { (Ribuan Rp. })\end{array}$ & $\begin{array}{c}\text { Bobot } \\
(\%)\end{array}$ & $\begin{array}{c}\text { Aktiva yang diklasifikasika } \\
\text { (Ribuan Rp.) }\end{array}$ \\
\hline PPAP & & & $\mathbf{3 4 . 4 2 4}$ \\
\hline PPAPWD & & & 143.826 .305 \\
- Lancar & 28.765 .261 & $0,5 \%$ & 0 \\
- Kurang lancar & 0 & $10 \%$ & 91.755 \\
- Diragukan & 183.510 & $50 \%$ & 383.027 \\
- Macet & 383.027 & $100 \%$ & $\mathbf{1 4 4 . 3 0 1 . 0 8 7}$ \\
Jumlah PPAPWD & & & \\
\hline
\end{tabular}

Sumber : Data Diolah

Perhitungan Rasio PPAP :

$R A S I O P P A P=\frac{P P A P}{P P A P W D} \times 100 \% \quad$ PPAP $2015=\frac{34.424}{547.982,9} \times 100 \%=$

$6.2 \%$ PPAP $2016=\frac{34.424}{144.301 .087} \times 100 \%=2,3 \%$

Perhitungan nilai kredit (NK) PPAP :

$$
N K 2015=\frac{6.2 \%}{1 \%}=6.2
$$

NK $2016=\frac{2.3 \%}{1 \%}=2.3$

BPR-JKT Pariaman Cabang Padang selama periode 2015-2016 tidak mampu menjaga rasio PPAP sebesar $81 \%$ sehingga berdasarkan kriteria penilaian rasio PPAP BPR-JKT Pariaman Cabang Padang dikategorikan dalam kelompok TIDAK SEHAT

3. Rentabilitas (Earnings)

Dalam penghitungan rentabilitas digunakan dua rasio yaitu Return on Asset (ROA) dan Rasio Biaya Operasional terhadap Pendapatan Operasional (BOPO). 
ROA adalah perbandingan laba sebelum pajak dengan rata-rata total aktiva, sementara BOPO adalah perbandingan pendapatan operasional.

Perhitungannya dapat dilihat dari tabel dibawah ini :

Tabel 7

Perhitungan Faktor Rentabilitas PT. BPR-JKT Pariaman

Cabang Padang tahun 2015-2016

\begin{tabular}{|c|c|c|}
\hline \multirow{2}{*}{ Komponen } & \multicolumn{2}{|c|}{ Tahun } \\
\hline & 2015 & 2016 \\
\hline Laba Sebelum Pajak & 1.097 .646 & 830.432 \\
\hline Total Aktiva & 25.707 .588 & 30.512 .806 \\
\hline Beban Operasional & 2.956 .240 & 3.259 .410 \\
\hline Pendapatan Operasional & 3.684 .746 & 4.107 .383 \\
\hline
\end{tabular}

Sumber : Laporan Keuangan PT. BPR-JKT Pariaman Cabang Padang

a. Perhitungan Rasio ROA

$$
\begin{gathered}
\text { ROA }=\frac{\text { Laba Sebelum Pajak }}{\text { Total Aktiva }} \times 100 \% \\
R O A 2015=\frac{1.097 .646}{25.707 .588} \times 100 \%=4,2 \% \\
R O A 2016=\frac{830.432}{30.512 .806} \times 100 \%=2,7 \%
\end{gathered}
$$

Perhitungan nilai kredit (NK) ROA

$$
\begin{aligned}
& \text { NK } 2015=\frac{4,2 \%}{0,015 \%}=280(\text { maksimum } 100) \\
& \qquad K K 2016=\frac{2,7 \%}{0,015 \%}=180(\text { maksimum } 100)
\end{aligned}
$$

Berdasarkan hasil perhitungan diatas, BPR-JKT Pariaman Cabang Padang mampu menjaga ROA tetap berada diatas $1,215 \%$ sehingga berdasarkan kriteria penilaian ROA BPR-JKT Pariaman Cabang Padang dapat dikategorikan SEHAT. Perhitungan rasio BOPO

$$
\begin{gathered}
B O P O=\frac{\text { Beban Operasional }}{\text { Pendapatan Operasional }} \times 100 \% \\
B O P O 2016=\frac{3.259 .410}{4.107 .383} \times 100 \%=79 \%
\end{gathered}
$$

Perhitungan Nilai kredit (NK) BOPO

$$
\begin{aligned}
& N K 2015=\frac{100 \%-80 \%}{0,08 \%}=250(\text { maksimum } 100) \\
& N K 2016=\frac{100 \%-79 \%}{0,08 \%}=262.5(\text { maksimum } 100)
\end{aligned}
$$

BOPO BPR-JKT Pariaman Cabang Padang pada tahun 2015 adalah sebesar 80\% dan ditahun 2016 sebesar 79\%. Berdasarkan hasil perhitungan tersebut, BPRJKT Pariaman Cabang Padang mampu menjaga BOPO tetap berada dibawah 93,52\% sehingga dapat dikategorikan dalam kelompok SEHAT.

3. Likuiditas (Liquidity)

Likuiditas adalah kemampuan untuk membayar kewajiban finansial jangka pendek tepat pada waktunya yang ditunjukkan oleh besar kecilnya aktiva lancar. Penilaian likuiditas dimaksudkan untuk mengevaluasi kemampuan Bank memelihara tingkat likuiditas yang memadai dan kecukupan manajemen resiko likuiditas 
Tabel 8

Perhitungan Faktor Likuiditas PT. BPR-JKT Pariaman

Cabang PadangTahun 2015-2016

\begin{tabular}{|c|c|c|}
\hline \multirow{2}{*}{ Komponen } & \multicolumn{2}{|c|}{ Tahun } \\
\hline & 2015 & 2016 \\
\hline $\begin{array}{l}\text { 1. Cash Ratio } \\
\text { a. Alat likuid } \\
\text { - Kas } \\
\text { - Antar Bank Aktiva } \\
\text { Jumlah } \\
\text { b. Hutang Lancar } \\
\text { - Kewajiban segera } \\
\text { - Tabungan } \\
\text { - Deposito } \\
\text { Jumlah }\end{array}$ & $\begin{array}{r}193.584 \\
6.113 .098 \\
\mathbf{6 . 3 0 6 . 6 8 2} \\
\\
11.571 \\
7.453 .175 \\
7.630 .950 \\
\mathbf{1 5 . 0 9 5 . 6 9 6}\end{array}$ & $\begin{array}{r}207.760 \\
3.453 .154 \\
\mathbf{3 . 6 6 0 . 9 1 4} \\
\\
33.738 \\
8.490 .928 \\
10.072 .400 \\
\mathbf{1 8 . 5 9 7 . 0 6 6}\end{array}$ \\
\hline $\begin{array}{l}\text { 2. Loan To Deposit Ratio } \\
\text { a. Kredit yang diberikan } \\
\text { b. Dana pihak ketiga dan Modal } \\
\text { - Tabungan } \\
\text { - Deposito } \\
\text { - Modal } \\
\text { Jumlah }\end{array}$ & $\begin{array}{r}7.453 .175 \\
7.630 .950 \\
3.122 .850 \\
\mathbf{1 8 . 2 0 6 . 9 7 5}\end{array}$ & $\begin{array}{r}8.490 .928 \\
10.072 .400 \\
3.122 .850 \\
\mathbf{2 1 . 6 8 6 . 1 7 8}\end{array}$ \\
\hline
\end{tabular}

Sumber: Data diolah

a. Perhitungan $\mathrm{CR}$

$$
\begin{gathered}
C R=\frac{\text { Alat likuid }}{\text { Hutang Lancar }} \times 100 \% \\
C R 2015=\frac{6.306 .682}{15.095 .696} \times 100 \%=41 \% \\
C R 2016=\frac{3.660 .914}{18.597 .066} \times 100 \%=19 \%
\end{gathered}
$$

Perhitungan nilai kredit (NK) CR

$$
\begin{gathered}
N K=\frac{\text { Angka rasio }}{0,05 \%} \times 1 \\
N K 2015=\frac{41 \%}{0,05 \%} \times 1=820 \\
N K 2016=\frac{19 \%}{0,05 \%} \times 1=380
\end{gathered}
$$

Cash Ratio BPR-JKT Pariaman Cabang Padang pada tahun 2015 sebesar 41\% dan tahun 2016 sebesar 19\% Berdasarkan hasil perhitungan tersebut, Cash Ratio BPR-JKT Pariaman Cabang Padang dapat dikategorikan dalam kelompok SEHAT. Untuk nilai kredit CR BPR-JKT Pariaman Cabang Padang tahun 2015 sebesar 820 dan tahun 2016 sebesar 380 maka dapat diakui sebagai 100.

b. Perhitungan rasio LDR

Perhitungan nilai kredit (NK) LDR

$$
\begin{gathered}
L D R=\frac{\text { Kredit yang diberikan }}{\text { Dana pihak ketiga }+ \text { modal }} \times 100 \% \\
L D R 2015=\frac{18.828 .879}{18.206 .975} \times 100 \%=103 \% \\
L D R 2016=\frac{25.878 .644}{21.686 .178} \times 100 \%=119 \%
\end{gathered}
$$

$$
N K=\frac{115 \%-\text { Angka rasio }}{1 \%} \times 4
$$




$$
\begin{aligned}
& N K 2015=\frac{115 \%-103 \%}{1 \%} \times 4=48(\text { maksimum } 100) \\
& N K 2016=\frac{115 \%-119 \%}{1 \%} \times 4=-16(\text { maksimum } 100)
\end{aligned}
$$

LDR BPR-JKT Pariaman Cabang Padang pada tahun 2015 sebesar 103\% dan tahun 2016 sebesar 119\%. Berdasarkan hasil perhitungan tersebut, BPR-JKT Pariaman Cabang Padang dapat dikategorikan dalam kelompok TIDAK SEHAT

\section{SIMPULAN}

Berdasarkan hasil analisis pada bab sebelumnya bahwa penelitian yang berjudul "Analisis Tingkat Kesehatan Bank Pada PT. Bank Perkreditan Rakyat (BPR) Jorong Kampuang Tangah Pariaman Cabang Padang" dapat disimpulkan sebagai berikut:

1. Capital (Permodalan) yaitu hasil CAR pada PT. BPR JKT Pariaman Cabang Padang untuk periode 2015-2016 berada dalam kategori sehat. Rasio permodalan yang diperoleh PT. BPR JKT Pariaman Cabang Padang selama tahun 2015-2016 adalah sebesar $15 \%$ dan $11 \%$ artinya masih di atas ketentuan yang ditetapkan Bank Indonesia yaitu $8 \%$.

2. Asset Quality (Kualitas Aktiva Produktif) yaitu KAP yang dimiliki PT. BPR JKT Pariaman Cabang Padang untuk periode 2015-2016 sebesar 0,01\%. Rasio PPAP yang diperoleh PT. BPR JKT Pariaman Cabang Padang selama tahun 2015-2016 adalah sebesar 6,2\% dan 2,3\% dinyatakan Tidak Sehat.

3. Rentabilitas (Earnings) yang didasarkan pada ROA dan PT. BPR JKT Pariaman Cabang Padang dikategorikan sehat karna mampu menjaga ROA dengan baik diatas $1,215 \%$.

4. Likuiditas (Likuidity) yang didasarkan pada cash ratio (CR) dalam dua tahun terakhir tergolong sehat, hal ini ditunjukkan dengan rasio yang dihasilkan yaitu sebesar $41 \%$ dan 19\%. Sedangkan untuk rasio LDR periode 2015-2016 berada dalam kategori Tidak Sehat, karena rasio LDR berada diatas $94,75 \%$.

\section{DAFTAR PUSTAKA}

Anggraeni, O. (2012). Penilaian Tingkat Kesehatan Bank Dengan Menggunakan Metode CAMEL Pada PT. Bank Pembangunan Daerah Jawa Tengah 2006-2009.

Budiasih, Y. (2012). Struktur Organisasi, Desain Kerja Terhadap Produktivitas Karyawan

Dendawijaya, L (2000). Manajemen Perbankan. Jakarta : Ghalia Indonesia

Hermawa. (2006). Manajemen Keuangan. Erlangga. Surabaya

Imamah, N. (2012). Analisis Camel Untuk Mengukur Tingkat Kesehatan Bank PT. BPR Syariah Al-Mabrur Kabupaten Ponorogo Periode 2004-2008. Profit, 6(2012, June), 70-84.

Jacob. (2013). Analisis Laporan Keuangan Dengan Menggunakan Metode Camel Untuk Menilai Ingkat Kesehatan Perbankan. Jurnal EMBA, 1(1), 691-700. https://doi.org/10.1007/s13398-014-0173-7.2 
Kaligis, Y. W. (2013). Analisis Tingkat Kesehatan Bank Dengan Menggunakan Metode Camel Pada Industri Perbankan Bumn Yang Terdaftar Di Bursa Efek Indonesia. Jurnal EMBA, 2631(3), 263-272.

Mandasari, J. (2015) Analisis Kinerja Keuangan Dengan Pendekatan Metode Rgec Pada Bank Bumn Periode 2012-2013.

Olivia, M. (2015.). Analisa Laporan Keuangan Dalam Mengukur Kinerja Keuangan Pada PT. Bank Artha Graha Internasional.

Permana, B. A. (2014). Analisis Tingkat Kesehatan Bank Berdasarkan Metode CAMELS dan Metode RGEC, 1-21.

Pratiwi, D. (2013). Analisa Laporan Keuangan Bank Dengan Metode Camel 